\title{
MULTIMEDIA KATALOG BERBASIS ANDROID DENGAN MENGGUNAKAN APLIKASI ADOBE FLASH PADA IDEKU DEKAL JERSEY SALATIGA
}

\author{
Ahmad Zainudin', Rujiono ${ }^{2}$ \\ ${ }^{1}$ Desain Grafis - Universitas STEKOM, zaenudin@stekom.ac.id \\ ${ }^{2}$ Desain Grafis - Universitas STEKOM, danielrudjiono@gmail.com \\ Jl. Majapahit 605, Semarang, telp/fax : 024-6717201-02
}

\section{ARTICLE INFO}

Article history:

Received 30 October 2020

Received in revised form 2 November 2020

Accepted 10 December 2020

Available online 17 December 2020

\begin{abstract}
Ideku dekal jersey salatiga is a creative economy business place in the field of sticker printing for vehicles and sportswear, where every product manufacture requires creative ideas from a designer in making patterns and motifs to make products that consumers want. However, most consumers choose images from Google and other printing companies, which affects designers who have to redesign a product design and pattern that makes production take longer.

Based on these problems, this study aims to create and design an interactive Multimedia Catalog in Ideku Dekal Jersey Salatiga using Adobe Flash software based on Android which can be made into 2 types that can be opened on computers and on Android-based cellphones which will make it easier. consumers who order online and can still view the catalog even though they are far away without having to come to Ideku Dekal Jersey Salatiga directly.
\end{abstract}

Keywords: Catalog Multimedia, Android, designer

\section{Pendahuluan}

Pada era modern ini banyak sekali perusahaan yang menggunakan multimedia sebagai alat dalam pemasaran suatu produk atau jasa kepada publik. Melalui multimedia inilah perusahaan dapat memberikan informasi tentang produk yang di pasarkan oleh perusahaan melalui audio maupun visual, hal ini menjadi nilai plus bagi perusahaan tersebut di bandingkan dengan perusahaan lain yang tidak menggunakan multimedia sebagai alat pemasaran apalagi di masa pandemik covid-19 seperti sekarang ini.

Perkembangan teknologi saat ini berkembang sangat cepat, khususnya dibidang smartphone. Hampir setiap hari keluar smartphone model terbaru. Smartphone itu sendiri merupakan telepon genggam yang mempunyai kemampuan dengan penggunaan dan fungsi yang menyerupai komputer yang bekerja menggunakan seluruh perangkat lunak sistem operasi yang menyediakan hubungan standar dan mendasar bagi pengembang aplikasi, yang menyajikan fitur-fitur canggih seperti surat elektronik, internet dan kemampuan membaca buku elektronik (e-book). Android merupakan sistem operasi yang perkembangannya sangat cepat. Saat ini, android sudah identik dengan smartphone.

Menurut Hofstede [1] mengatakan bahwa multimedia merupakan sebuah kombinasi tiga elemen yaitu suara, gambar dan teks yang di gunakan untuk memberikan informasi. Dikarenakan multimedia merupakan gabungan dari beberapa elemen hal ini yang membuat multimedia menjadi daya tarik tersendiri di karena menarik imajinasi dan minat konsumen dengan alat bantu (tool) dan koneksi (link) pengguna dapat bernavigasi dan berinteraksi. 
Ideku Dekal Jersey, Sebuah usaha Sticker dan Jersey yang didirikan pada tanggal 18 Juni 2014 lalu oleh Muslimin. Ideku Dekal Jersey Salatiga perusahaan percetakan stiker kendaraan atau sering di sebut Decal, termasuk desain cetak kaos, jersey atau seragam olahraga, topi dan lain lain.

Secara umum sistem yang sedang berjalan di Ideku Dekal Jersey Salatiga meliputi prosedur pemesanan, prosedur desain, prosedur persetujuan, prosedur produksi, dan prosedur laporan adalah sebagai berikut :

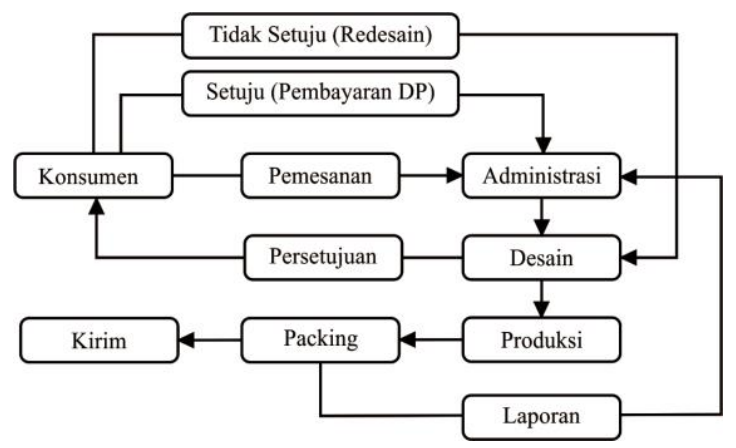

a. Prosedur Pemesanan

Gambar 1. Sistem lama alur pemesanan pada Ideku Dekal Jersey Salatiga

Awal mula konsumen dapat memesan produk melalui datang langsung ke Ideku Dekal Jersey Salatiga kemudian bertemu langsung dengan administrasi untuk membahas tetang produk yang di pesan.

b. Prosedur Desain

Desainer menerima pesanan dari buku yang di tulis oleh administrasi kemudian mendesain produk tersebut sehingga sesuai yang di inginkan konsumen.

c. Prosedur Persetujuan

Setelah desain selesai maka gambar desain di kirim ke konsumen untuk mengkonfirmasi konsumen, jika konsumen kurang setuju dengan desain tersebut maka desainer kembali membuat desain yang di inginkan konsumen dan dan jika konsumen setuju dengan hasil desain maka konsumen dapat membayar DP (down payment) sehingga desain siap untuk di produksi.

d. Prosedur Produksi

Setelah bukti pembayaran DP dari konsumen di terima oleh administrasi, maka desainer mengirim file desain ke bagian produksi untuk di teliti kekurangannya sebelum di cetak. Setelah selesai di teliti maka desain tersebut di cetak.

e. Prosedur Laporan

Setelah selesai di cetak makan produk di paking terlebih dahulu, sebelum produk di kirim ke konsumen. Administrasi mencatat dan melaporkan bahwa produk yang di pesan oleh konsumen sudah melalui proses produksi dan siap untuk di kirim ke konsumen di buku laporan.

Menghadapi masa pandemi Covid-19 ini, banyak pelanggan yang kebingungan dalam memesan stiker apalagi datang langsung ke Ideku Decal Jersey, dan masih adanya himbauan pemerintah tentang antisipasi penyebaran covid-19 untuk tetap dirumah.

Untuk mengatasi masalah tersebut perusahaan yang bergerak di bidang percetakan stiker kendaraan ini sudah membuat katalog yang berbentuk sebuah gambar akan tetapi tidak di cetak masih dalam bentuk file gambar, yang membuat kebanyakan konsumen lebih memilih gambar katalog perusahaan lain / gambar dari internet untuk di buatkan di Ideku Dekal Jersey Salatiga yang berimbas kepada waktu produksi dan sering mendapatkan revisi dari konsumen.

Masalah tersebut yang mendasari penulis untuk membuatkan sebuah Katalog Multimedia sebagai alat untuk mempermudah konsumen dalam memilih sebuah pola atau desain produk, sekaligus dapat mempercepat produksi di karenakan desainer tidak perlu mendesain ulang pola yang di pilih konsumen.

\section{Landasan Teori}

Berikut ini adalah beberapa teori yang digunakan dalam penelitian ini. 


\section{a. Desain Grafis}

Desain grafis diterapkan dalam desain komunikasi dan fine art. Seperti jenis komunikasi lainnya, desain grafis dapat merujuk kepada proses pembuatan (mendesain) ataupun produk yang dihasilkan (desain/rancangan). Desain grafis pada awalnya diterapkan untuk media-media statis, seperti buku, majalah, dan brosur. Sebagai tambahan, sejalan dengan perkembangan zaman, desain grafis juga diterapkan dalam media elektronik - yang sering kali disebut sebagai "desain interaktif" (interactive design), atau "desain multimedia" (multimedia design') [2]

Desain grafis menerapkan beberapa prinsip, yakni: Kesederhanan, Keseimbangan, Kesatuan, Penekanan, dan Repetisi. Sedangkan elemen-elemen yang diusungnya meliputi garis, bentuk, ruang, tekstur, dan warna. Dan pada akhirnya sang penikmat karya visual seakan memberikan penilaian, Nilai Estetis dan Nilai Ekstra. Nilai estetis diperoleh melalui penggunaan elemen-elemen dan prinsip-prinsip. Sedangkan nilai ekstra muncul: gerakan (animasi), percepatan, lambaian, suasana panas, atmosfer tenang dan lain sebagainya.

\section{b. Multimedia}

Multimedia adalah kombinasi dari beberapa unsur yang terdiri dari audio (suara atau musik), animasi, teks, grafik, dan gambar. Multimedia juga merupakan alat yang dapat menciptakan presentasi yang dinamis dan interaktif yang mengkombinasikan unsur-unsur di atas. Multimedia memungkinkan pemakai komputer untuk mendapatkan output dalam bentuk yang jauh lebih kaya dari pada media table dan grafik konvensional. Pemakai dapat melihat gambar tiga dimensi, foto, video bergerak, animasi, mendengar suara stereo, perekaman suara, atau musik. Bersifat interaktif pada beberapa sistem multimedi memungkinkan pemakai memilih output dengan mouse atau kemampuan layar sentuh dalam menjalankan aplikasi tersebut. Multimedia dibagi menjadi beberapa jenis berdasarkan teknik pengoprasianya. Hal tersebut dijelaskan dalam sebuah buku yang berjudul Multimedia Digital [6] membagi jenis multimedia menjadi 3 yaitu: Multimedia Interaktif, Multimedia Hiperaktif, Multimedia linear

\section{c. Tipografi}

Tipografi dalam Desain Grafis tipografi merupakan salah satu elemen yang penting dalam desain. Tipografi berfungsi sebagai elemen pelengkap dalam desain, bisa dikatakan tipografi merupakan visual language atau bahasa yang dapat dilihat [4]. Dianggap sebagai elemen pelengkap karena tipografi berfungsi untuk menjelaskan elemen desain yang lain seperti konsep dan ilustrasi dalam desain. Tipografi terdiri dari susunan huruf yang membentuk rangkaian kata. Berdasarkan garis besarnya jenis huruf dalam tipografi dapat diklasifikasikan menjadi tiga jenis yaitu Blackletter, Serif dan Sans Serif.

\section{d. Pengertian Katalog}

Pengertian katalog promosi menurut Kotler \& Amstrong adalah daftar informasi tentang produk - produk yang dijual oleh satu perusahaan atau agen pemasaran[9]. Tujuannya adalah untuk memberi cukup informasi tentang produk - produk tersebut sehingga memudahkan konsumen untuk memilih produk yang diinginkannya.

\section{e. Animasi}

Animasi merupakan suatu pergerakan yang dibuat pada suatu gambar maupun teks, dengan menggunakan animasi pergerakan gambar atau teks terlihat lebih hidup, 3D adalah pengembangan dari animasi 2D. Animasi 3D karakter yang diperlihatkan semakin hidup dan nyata, mendekati wujud manusia aslinya [11].

\section{f. Android}

Dalam kehidupan sehari-hari sering dijumpai berbagai hal yang berkaitan dengan penggunaan smartphone mulai dari anak-anak sampai yang lebih tua. Di dalam smartphone itu sendiri telah dibenamkan sistem operasi yang sering disebut android. Android adalah sistem operasi yang digunakan di smartphone dan juga tablet PC. Android juga merupakan subset perangkat lunak untuk ponsel yang meliputi sistem operasi, middleware dan key application yang direlease oleh google. Saat ini disediakan android SDK (Software 
Development Kit) sebagai alat bantu dan API (Application Programming Interface) diperlukan untuk mulai mengembangkan aplikasi pada platform android menggunakan bahasa pemrograman java [13]

\section{Hasil dan Pembahasan}

Penelitian ini membahas tentang katalog multimedia menggunakan Adobe Flash berbasis Android. Teknik pengujian dilakukan dengan blackbox testing. Penelitian dan pengembangan aplikasi ini menggunakan metode penelitian Research and Development $(\mathrm{R} \& \mathrm{D})$ yaitu metode penelitian yang bertujuan menghasilkan produk tertentu serta menguji efektivitas produk. Adapun yang dibahas dalam aplikasi ini yaitu Katalog Multimedia berbasis android serta menampilkan model-model stiker dan jersey kendaraan berbagai merek dan cetak kaos, topi dan lain lain. Aplikasi ini diuji dengan pengujian blackbox yang menunjukkan bahwa aplikasi ini telah memenuhi syarat dan mendapatkan keluaran sesuai yang diharapkan. Adapun tahapan sebelum membuat aplikasi ini mulai dari mengumpulkan data yang dibutuhkan menggunakan metode wawancara, observasi, dan studi pustaka.

Tahapan selanjutnya dilakukan identifikasi kebutuhan materi seperti kebutuhan aplikasi yang digunakan dalam pembuatan aplikasi, kebutuhan user, dan menentukan tujuan dari aplikasi ini dibuat. Kemudian dalam pembuatan desain user interface berbasis android dan gambar marker menggunakan Corel Draw dan Photoshop. Tahap selanjutnya adalah memasukkan gambar tersebut kedalam Adobe Flash yang kemudian akan di eksport dalam Android, penataan layout dibuat berdasarkan hasil desain pada storyboard pada tahap desain, lalu Membuild aplikasi yang sudah dibuat ke dalam bentuk apk maka dibutuhkan Java Development Kit (JDK) dan Software Development Kit (SDK) untuk menjalankan program di android.

Tampilan awal desain multimedia decal ini terdapat 4 menu yaitu :
a. Decal
b. Produk lain
c. Gallery
d. Informasi

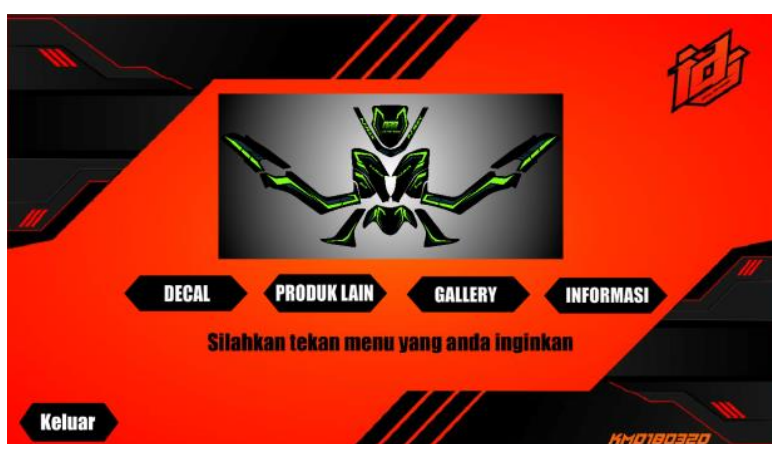

Gambar 2. Beranda

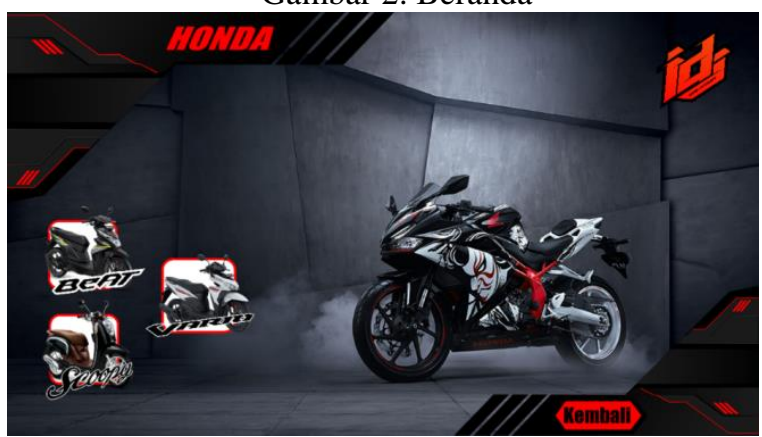

Gambar 4. Halaman Honda

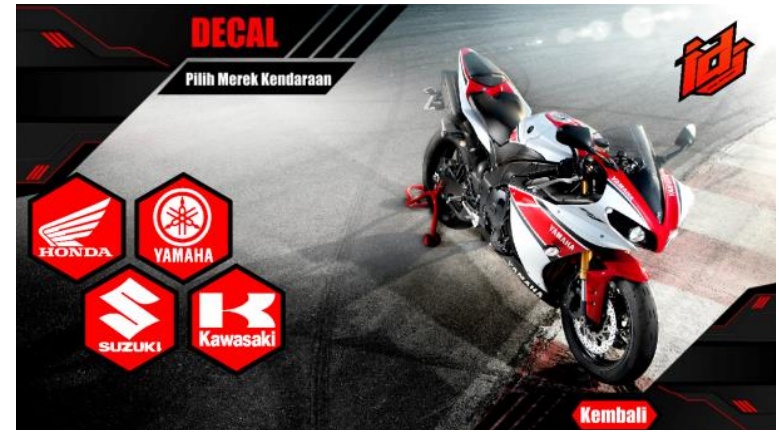

Gambar 3. Halaman Decal

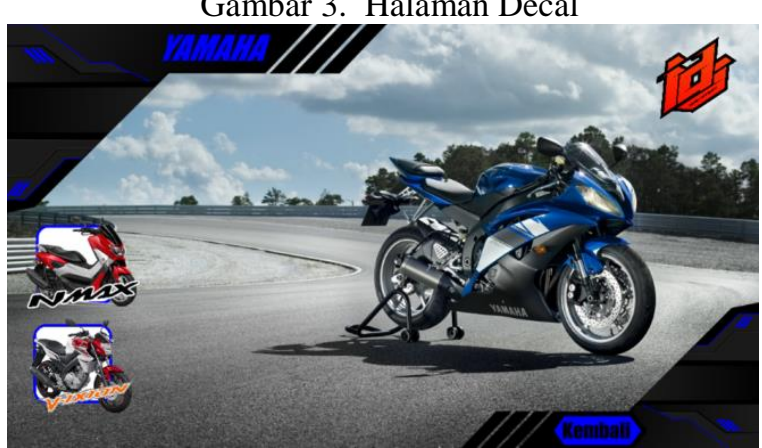

Gambar 5. Halaman Yamaha 


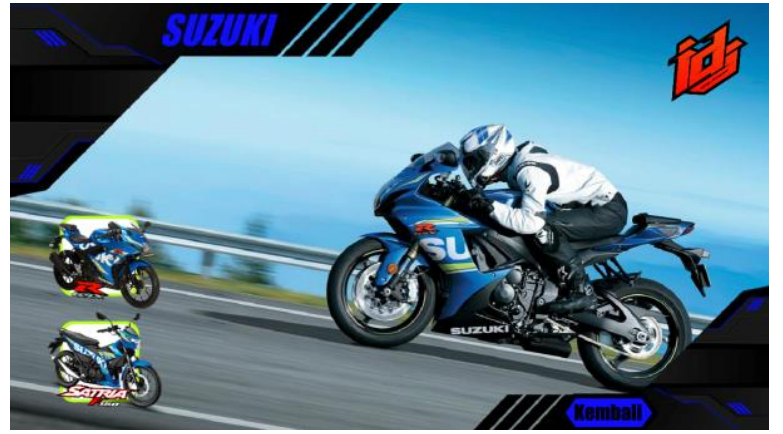

Gambar 6. Halaman Suzuki

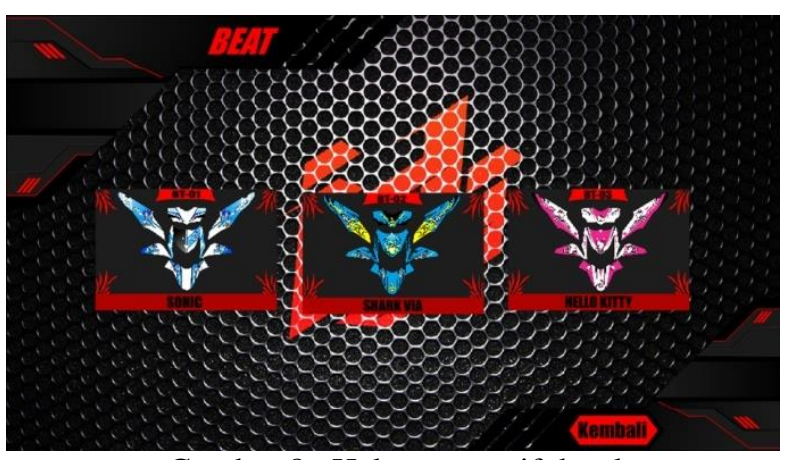

Gambar 8. Halaman motif decal

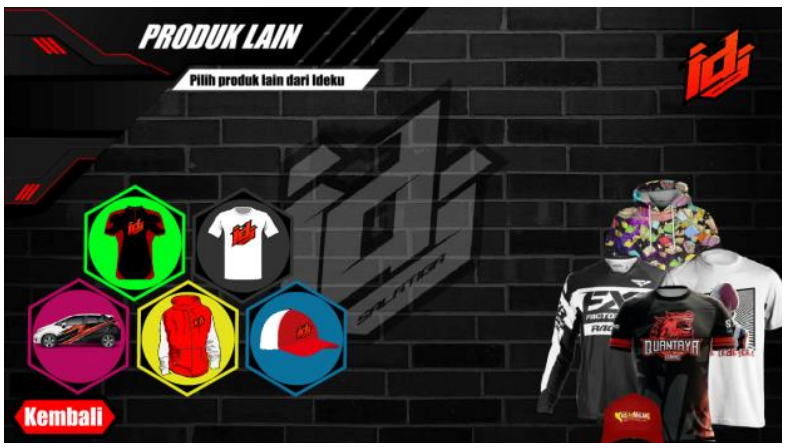

Gambar 10. Halaman Produk Lain

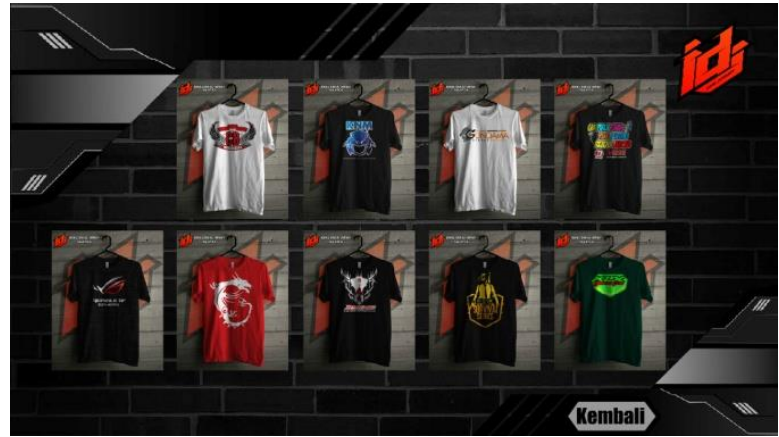

Gambar 12. Halaman kaos

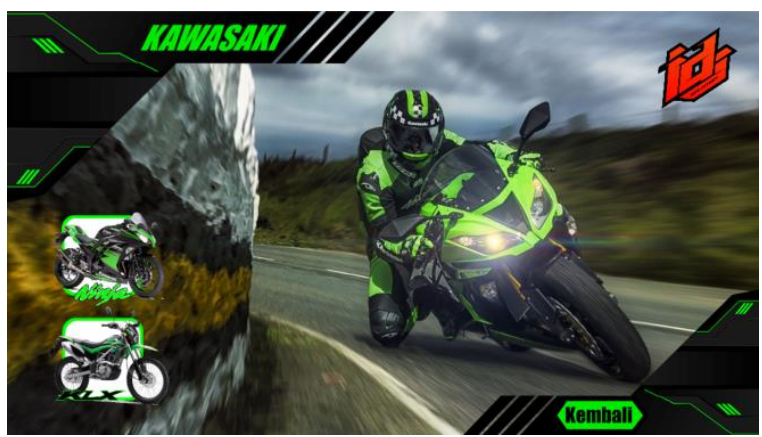

Gambar 7. Halaman Kawasaki

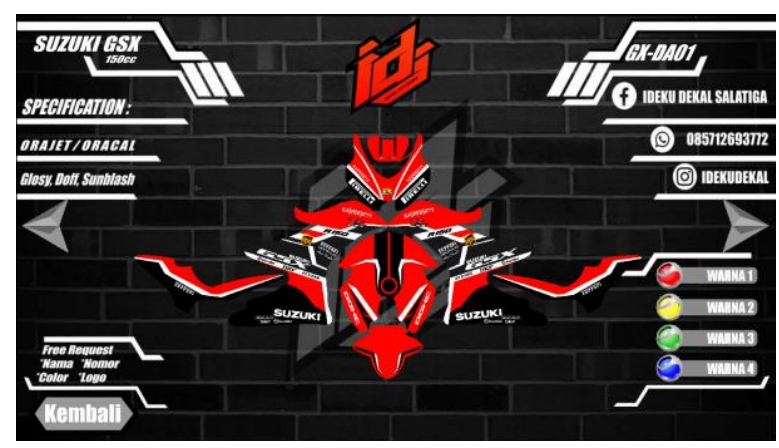

Gambar 9. Halaman informasi decal

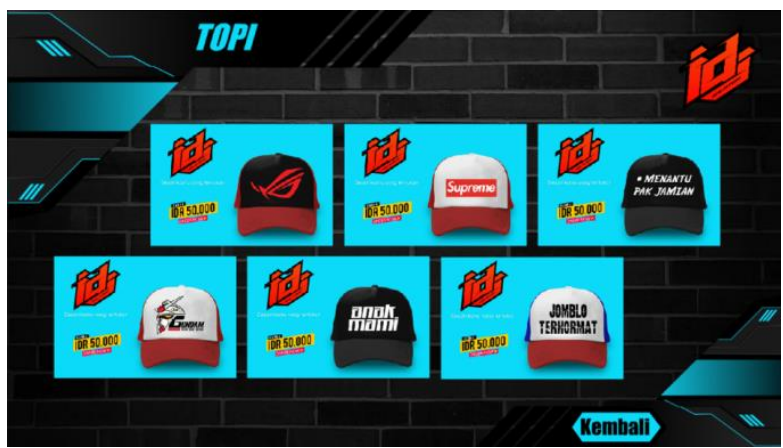

Gambar 11. Halaman Topi

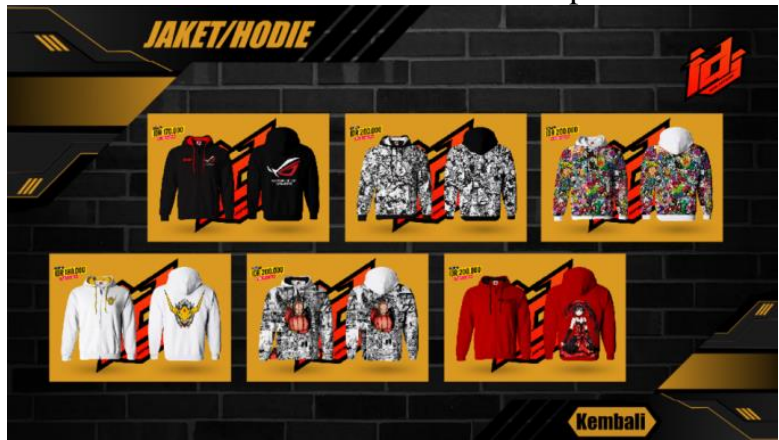

Gambar 13. Halaman Jaket/Hodie 


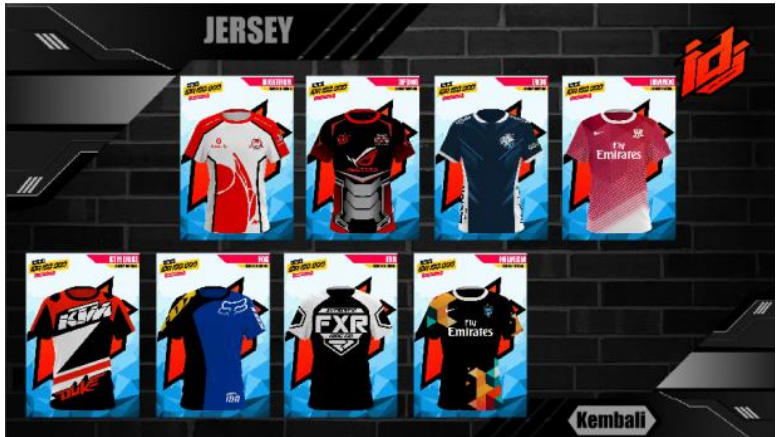

Gambar 14. Halaman Jersey

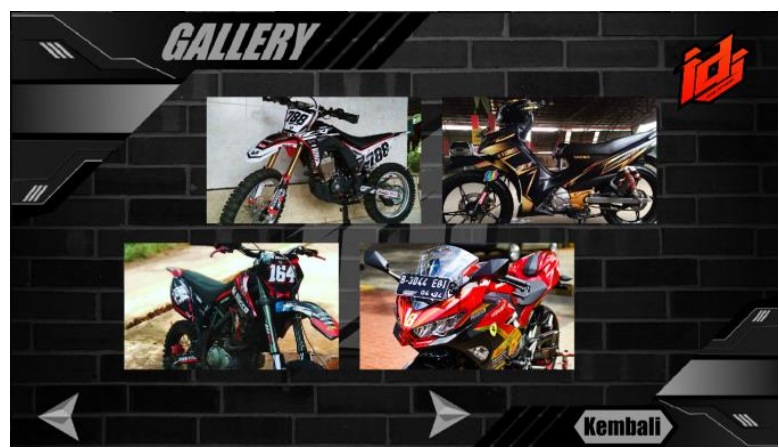

Gambar 16. Halaman Gallery

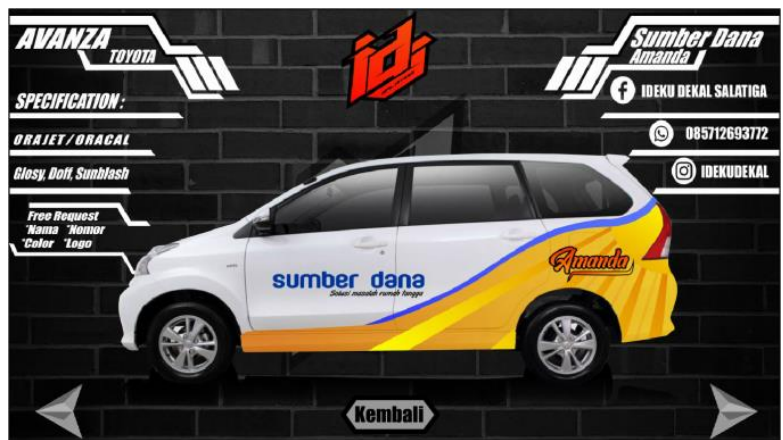

Gambar 15. Halaman Decal Mobil

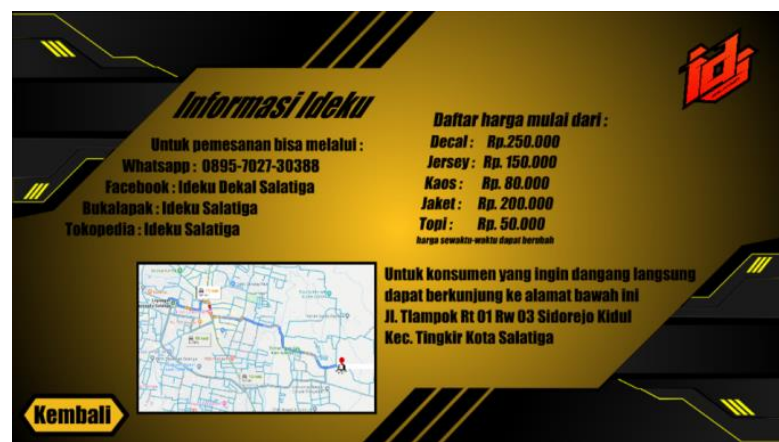

Gambar 17. Halaman Informasi

Aplikasi Katalog Multimedia ini dinilai oleh konsumen, dan dosen ahli untuk mengetahui kesesuaian informasi, kemudahan penggunaan aplikasi, manfaat aplikasi dan kesesuaian audio visual terhadap isi aplikasi. Kategori dan hasil penilaian ini dapat dilihat pada tabel di bawah ini.

Tabel 1. Hasil Penilaian

\begin{tabular}{lll}
\hline Presentase Nilai & Kategori Nilai & Hasil \\
\hline $81-100 \%$ & Sangat baik & $82.76 \%$ \\
$61-80 \%$ & Baik & \\
$41-60 \%$ & Cukup baik & \\
$21-40 \%$ & Tidak baik & \\
$1-20 \%$ & Sangat tidak baik & \\
\hline
\end{tabular}

Sumber : Hasil olah data

Berdasarkan hasil penilaian menunjukkan bahwa presentase hasil penilaian aplikasi Katalog Multimedia adalah sebesar $82.76 \%$. Hal ini menunjukkan bahwa menurut konsumen, aplikasi ini sangat baik untuk diterapkan dalam pemesanan Sticker dan Jersey, serta termasuk desain cetak kaos, topi, jakaet dan lain lain..

\section{Simpulan}

Berdasarkan hasil penelitian dari pengujian pembuatan aplikasi Katalog Multimedia dapat diambil kesimpulan sebagai berikut:

a. Katalog multimedia decal yang telah dibuat ini merupakan sarana perusahaan sebagai alat yang dapat digunakan konsumen ketika kesulitan dalam memilih sebuah pola decal yang akan di pesan oleh konsumen dan juga dapat mempermudah desainer.

b. Katalog multimedia decal di buat berdasarkan konsep desain yang sesuai dengan kebutuhan dan karakteristik perusahaan. 


\section{Saran}

Adapun saran yang di sampaikan penulis kepada perusahaan, supaya perusahaan dapat menggunakan katalog multimedia decal ini sebagai sarana untuk mempermudah konsumen dalam memilih sebuah pola decal tanpa harus menggunakan pola dekal dari perusahaan lain yang telah memiliki katalog, hal ini dapat membuat panjangnya waktu dalam pesanan sebuah dekal. Dengan adanya Katalog multimedia decal ini permasalahan konsumen dalam memilih pola desain dapat di atasi.

\section{DAFTAR PUSTAKA}

[1] Darmawan, D. (2011). Teknologi Pembelajaran. Bandung: PT.Rosdakarya Offset.

[2] Kusriandi, A. (2009). Berkarir di Dunia Grafis. Jakarta: PT.Elex Media Computindo.

[3] Binanto, I. (2010). Multimedia Digital Dasar Teori dan Pengembangannya. Yogyakarta: Andi.

[4] Kotler, P., \& Amstrong, G. (2014). Principle Of Marketing. New Jersey: Pearson Prentice Hall.

[5] Sugiyono, 2014. Metode Penelitian Kuantitatif Kualitatif dan R\&D, Bandung: Alfabeta.

[6] Hakim, Z. (2012). Mengenal layout desain. Retrieved Juli 31, 2018, from zainalhakim.web.id: www.http://www.zainalhakim.web.id/posting/mengenal-layout-

desain.html.web.id/posting/mengenal-layout-desain.html

[7] Prabawati, T. A. (2009). Shortcouse: Desain Grafis dengan CorelDRAW X4. Yogyakarta: Andi.

[8] Redono, D. (2013). SIMPLE PROMOTION dan BRANDING untuk USAHA KECIL MENENGAH. Malang: Universitas Brawijaya Press (UB Press).

[9 ] Vaughan, T. (2006). Multimedia Making it Work. Yogyakarta: Andi.

[10] Sihombing, D. (2001). Tipografi dalam Desain Grafis. Jakarta: Gramedia.

[11] Sitepu, V. (2004). Panduan Mengenal Desain Grafis. PT. Elex Media.

[12] Suhendar, Y. (2007). Pedoman Katalogisasi. Jakarta: Kencana.

[13] Darma prawira, S. (2002). Teori dan Kreatifitas Penggunanya. Bandung: Institute Teknologi Bandung (ITB). 